\title{
Valuing Environmental Amenities in Peri-Urban Areas: Evidence from Poland
}

\author{
Marta Sylla ${ }^{1,2, * \mathbb{D}}$, Tadeusz Lasota ${ }^{1}$ and Szymon Szewrański ${ }^{1}$ (D) \\ 1 Faculty of Environmental Engineering and Geodesy, Department of Spatial Economy, \\ Wroclaw University of Environmental and Life Sciences, Grunwaldzka 55, 50-357 Wroclaw, Poland; \\ tadeusz.lasota@upwr.edu.pl (T.L.); szymon.szewranski@upwr.edu.pl (S.S.) \\ 2 Technische Universität Dresden, International Institute Zittau, Markt 23, 02763 Zittau, Germany \\ * Correspondence: marta.sylla@upwr.edu.pl or marta.sylla@tu-dresden.de; Tel.: +48-508-658-055
}

Received: 10 December 2018; Accepted: 17 January 2019; Published: 22 January 2019

check for updates

\begin{abstract}
Ecosystems provide services that contribute to the well-being of people living within a city's borders and on the urban-rural fringe. While benefits from green areas in urban settings are well investigated, peri-urban areas are significantly less addressed by researchers than cities. This study aims to evaluate the importance of environmental amenities in peri-urban areas using the hedonic pricing method to assess people's willingness to pay for environmental goods and services. A local regression model (geographically weighted regression) and two global regression models (generalized spatial two-stage least squares and ordinary least square) are used to identify the spatial patterns and level of influence of protected areas, forests, rivers, trees, and landscape diversity. This paper includes the Central European case study example of a peri-urban area of the city of Wroclaw, Poland. The results from the three models show that out of all of the environmental amenities included in this study, proximity to protected areas—-such as Natura 2000 sites and landscape parks-and the diversity of land-use patches within the 500-m radius around the sites exert the strongest influence on plot prices. The overall impact of environmental amenities on vacant plot prices in peri-urban areas is low or, as in the case of river and streams, not significant. The results of the analysis reveal the preferences of the new peri-urban inhabitants concerning green spaces that have an effect on the real estate market in Poland.
\end{abstract}

Keywords: hedonic pricing; geographically weighted regression; peri-urban; ecosystem service; environmental valuation; protected areas

\section{Introduction}

Ecosystems bring benefits to people [1-3] and improve their quality of life [4] both within the city borders and in the surrounding areas. A growing urban population increases the demand for ecosystem services in cities and the sprawling areas around them [5]. In many parts of the world, and in our case in Central Europe, the rural-urban fringe is growing in terms of the number of inhabitants and housing developments, which have transformed rural landscapes [6]. Land-use patterns analyses show that the benefits from green areas in the city surroundings are higher than those within the city's administrative units [7].

The importance of green spaces can be determined using monetary and non-monetary valuation methods [8]. Among other monetary methods, hedonic pricing enables examining the influence of environmental amenities on the real estate prices, and therefore reflects people's willingness to pay for environmental goods and services [9-12]. Most authors build regression models to explain the sale prices of houses and apartments [13,14], and some also use housing rents [15]. House prices or rents vary considerably, depending on the structural characteristics of the real estate. To allow 
for the elimination of all of the factors concerning the state, quality, and characteristics of housing developments from imposing any influence on a price, we use vacant lots that do not possess any developments at any stage, i.e., ready-made houses or a house under construction. This approach has already been successfully applied by Łowicki and Piotrowska [16] in the context of road noise.

Hedonic analyses have been conducted at different spatial scales, mainly representing administrative units, i.e., a county [17] or municipality [18] and its districts [19], sub-national [20], and country [21]. The peri-urban context [22] has not yet been well described in the hedonic pricing literature. Therefore, our research extends the existing body of valuation literature of environmental amenities with a peri-urban hedonic pricing case study and discusses its practical implications for authorities being responsible for the peri-urban environment. The suburban scale, which partly overlaps with the peri-urban areas, has been investigated by Schläpfer et al. [15] and Helbich [23]. The latter author reported on evidence of the stratification of the housing market in the suburbs. Nilsson [24] found significant intraregional heterogeneity regarding the values of open green space amenities. Her results indicated that in the peripheral and rural areas, the marginal effects of such amenities are low or insignificant in comparison to cities [24].

In order to sustainably plan land-use practices at the urban-rural fringe, it is important to examine the influence of environmental amenities on the real estate prices here [25]. Therefore, the objective of this paper was twofold: (i) to explore the relationships of the selected environmental amenities and the price of a land parcel for single-family housing lots in peri-urban areas, and (ii) to reveal preferences concerning the selected environmental amenities in the peri-urban areas of a major city in Poland. Our research focused on the recreational potential of the forests, rivers, and environmental conservation areas. We aimed to elicit the importance of the forest area within walking distance; therefore, we applied the indicators of the surface area of forests within radiuses of $500 \mathrm{~m}, 500-1500 \mathrm{~m}$, and 1500-3000 m. We also analyzed the distances to delineated Natura 2000 sites according to the Habitats and Birds Directives, landscape parks, and Oder river and its streams. In order to account for the spatial variation of factors, we used a local model-geographically weighted regression (GWR)—and two global models: generalized spatial two-stage least squares (GSTSLS) and ordinary least square regression (OLS).

\section{Materials and Methods}

\subsection{Peri-Urban Study Area}

The term "peri-urban" refers to areas located within the urban-rural fringe, which is also called the urban-rural transition zone. Peri-urban areas are characterized by relatively low population density compared to urban areas, scattered housing developments, high dependence on (very often individual) transport for commuting, fragmented communities, and weak spatial governance [26]. Peri-urban areas undergo significant pressures (such as population migration [27]) from nearby urban centers. There is no commonly agreed definition of peri-urban areas, as they are rather defined by their characteristics. There are also several approaches to delimitate these areas. We applied the administrative boundaries approach and eliminated the central city from the analysis. We decided on this approach due to real estate market characteristics, data availability, and spatial management according to the administrative division of the region.

The study has been conducted in 10 peri-urban municipalities around the city of Wroclaw, in the Lower Silesia region in the southwestern part of Poland (Figure 1). The case study area covers $1430 \mathrm{~km}^{2}$, and constitutes a major part of the Wroclaw metropolitan area. The average density of the population is 117 person $/ \mathrm{km}^{2}$, which has been increasing due to the urban sprawl processes [28]. The area is under various pressures of the neighboring city of Wrocław (637,000 inhabitants) [29-34]. The case study area, which is presented in Figure 1, represents the rather typical peri-urban landscape in Central Europe. The main river flowing through the case study area is the Oder river. There are 10 patches of Natura 2000 sites in the case study area, and one 5149-ha patch of the landscape park of 
the Bystrzyca river valley. Forests are located in the northern and eastern parts of the case study area (Figure 1).

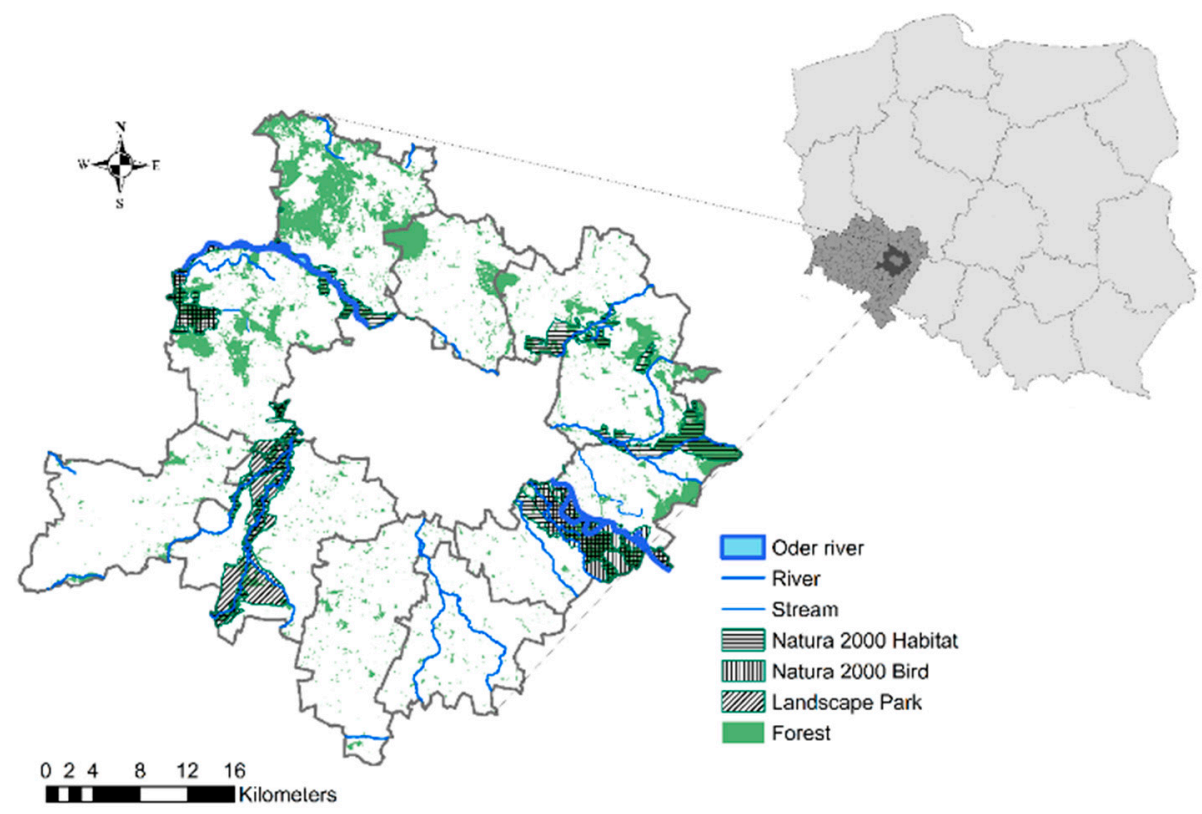

Figure 1. The location of the case study area around the city of Wroclaw in Poland.

\subsection{Data}

The register of transactions, which was provided by the geodetic departments of the municipal administration, consisted of all of the transactions of land parcels taking place between January 2004 and June 2016. After consulting real estate appraisers, we applied several criteria to elicit the land parcels devoted to the single-family detached housing, such as the purchase being a market transaction, and the master plan or spatial managing documents defining the function of the area as single-family housing. We have tested the regression results of several combinations of sets of data, and we received the best results in terms of the Akaike information criterion (AIC) and $R^{2}$ for parcels between $600-2000 \mathrm{~m}^{2}$ and the price of $1 \mathrm{~m}^{2}$ varying between $10(\sim \$ 2.5)$ and 400 PLN $(\sim 101)$. The analysis of price trends proved the increased influence of the 2008 and 2009 boom in housing and its subsequent recession. Therefore, we have only included the transitions of the stable trend between January 2012 and June 2016 when the market returned to the state before the boom. That final database included 2645 valid observations.

Having the observations selected, we assumed that they might share some common characteristics; therefore, we checked for spatial clusters. A recognized tool to measure the degree of clustering of variables is the general Getis-Ord Gi test [35]. The general Getis-Ord Gi clustering result of the z-score revealed that there is less than a $1 \%$ likelihood that the high-clustered pattern of parcels' prices per square meter could be the result of random chance. After conducting the hot spot analysis based on the Getis-Ord $\mathrm{Gi}^{*}$ statistics, we discovered the spatial clustering patterns displayed in Figure 2. There are groups of transaction values that are significantly above the regional average clustered at the southern and northeast edges of the city of Wroclaw, where the distance to the city center is the shortest (see Figure 2). Along with the increasing distance from the city center, the prices fall below the regional average. The strong clustering patterns have also been confirmed by the global Moran I test $(I=0.342$; z-score: $11.433 ; p<0.001)$. Our case study values are in line with land rent theory, which says that the highest land rent can be obtained in the center or center business district, and then the values fall according to the distance decay function. 


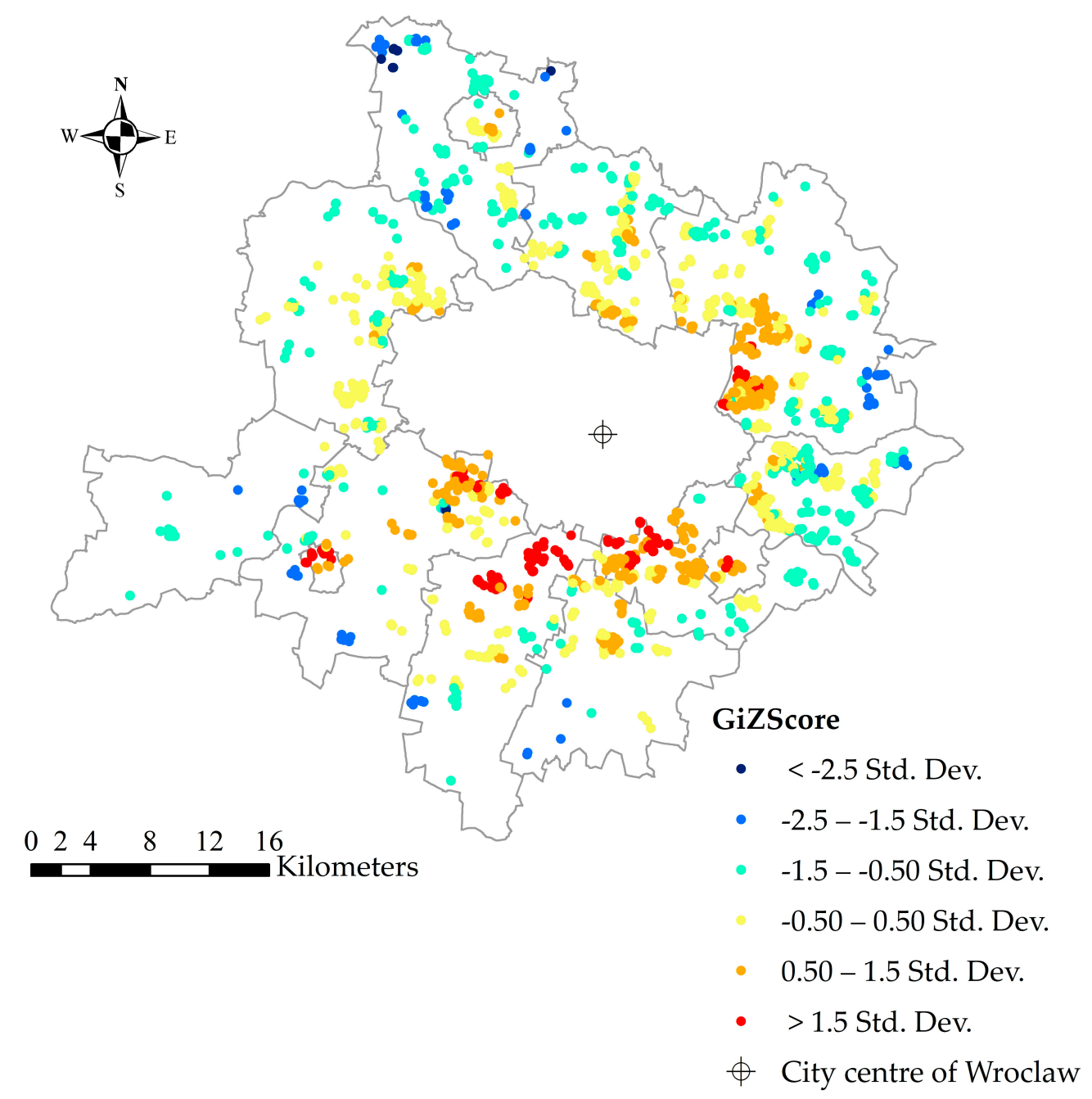

Figure 2. The results of parcel values' hot spot analysis based on the Getis-Ord Gi* statistics and classified with standard deviations.

\subsection{The Variables}

Table 1 presents the descriptive statistics of 28 explanatory variables. The dependent variable is the price per square meter. There are 14 environmental variables included in the analysis, such as trees, open green space (forest, streams, and river), landscape metrics, and protected areas. In terms of trees, we use the indicator of the number of trees. Open green spaces are described by distance and size. The landscape metrics used in our study are patch richness, Shannon's diversity index of different land-use patches, and forest edge density. The distance decay function suggests that only the closest amenities matter statistically and add to the price of parcels. Therefore, we include only landscape metrics and trees in the radius of $500 \mathrm{~m}$. In our study, the vector of structural characteristics is limited, because we use vacant lots, which except for the location are very similar to each other. All of the parcels in our study are devoted to single-family housing and have the direct availability of electricity and a water supply system. We do not possess the information of whether all the parcels have outline planning decisions. 
Table 1. Descriptive statistics of the variables.

\begin{tabular}{|c|c|c|c|c|c|c|c|}
\hline Variable & Description & Unit & Mean & Min & Max & Std. dev & $\begin{array}{l}\text { Expected } \\
\text { sign* }\end{array}$ \\
\hline Price & Price per square meter & $\mathrm{PLN} / \mathrm{m}^{2}$ & 108.14 & 10.85 & 393.35 & 61.99 & $\mathrm{n} / \mathrm{a}$ \\
\hline \multicolumn{8}{|c|}{ Locational and neighborhood variables } \\
\hline Dist_center & Distance to the Wroclaw city center & $100 \mathrm{~m}$ & 144.95 & 63 & 337.30 & 45.21 & - \\
\hline Dist_provincial road & Distance to the nearest provincial level road & $100 \mathrm{~m}$ & 35.17 & 0.20 & 159.50 & 30.96 & + \\
\hline Dist_national road & Distance to the nearest national level road & $100 \mathrm{~m}$ & 49.04 & 0.10 & 182.30 & 33.61 & + \\
\hline Dist_highway & Distance to the nearest highway & $100 \mathrm{~m}$ & 82.19 & 1.60 & 233.50 & 50.38 & - \\
\hline Dist_railway & Distance to the nearest railway line & $100 \mathrm{~m}$ & 18.36 & 0.30 & 88.70 & 14.16 & - \\
\hline Dist_Rail_station & Distance to the nearest railway station & $100 \mathrm{~m}$ & 29.17 & 1.20 & 125.30 & 17.42 & + \\
\hline Dist_stop & Distance to the nearest bus/tram stop & $100 \mathrm{~m}$ & 4.53 & 0.10 & 19.30 & 2.39 & - \\
\hline Dist_intersect & Distance to the transportation hub & $100 \mathrm{~m}$ & 56.83 & 0.80 & 163.20 & 30.49 & - \\
\hline Dist_primaryschool & Distance to the nearest primary school & $100 \mathrm{~m}$ & 16.59 & 0.40 & 58.20 & 10.42 & - \\
\hline Dist_middleschool & Distance to the nearest middle school & $100 \mathrm{~m}$ & 28.77 & 0.60 & 135.30 & 19.57 & - \\
\hline Dist_highschool & Distance to the nearest high school & $100 \mathrm{~m}$ & 63.29 & 1.00 & 209.50 & 30.57 & - \\
\hline Area_Ind $\mathrm{r}=500$ & $\begin{array}{l}\text { Industrial built-up area and storage sites in the } \\
500-\mathrm{m} \text { radius }\end{array}$ & ha & 0.99 & 0.00 & 29.61 & 2.09 & - \\
\hline Area_ind $r=500-1500$ & $\begin{array}{l}\text { Industrial built-up area and storage sites in the } \\
\qquad 500-1500-\mathrm{m} \text { radius }\end{array}$ & ha & 5.77 & 0.00 & 54.16 & 7.80 & - \\
\hline Area_Ind $\mathrm{r}=1500-3000$ & $\begin{array}{l}\text { Industrial built-up area and storage sites in the } \\
\text { above } 1500-\mathrm{m} \text { radius }\end{array}$ & ha & 17.44 & 0.00 & 133.62 & 19.52 & - \\
\hline \multicolumn{8}{|c|}{ Environmental variables } \\
\hline Dist_Natura_bird & $\begin{array}{l}\text { Distance to the nearest Natura } \\
2000 \text { Bird Directive }\end{array}$ & $100 \mathrm{~m}$ & 90.70 & 0.50 & 237.10 & 54.05 & - \\
\hline Dist_Natura_hab & $\begin{array}{l}\text { Distance to the nearest Natura } \\
2000 \text { Habitat Directive }\end{array}$ & $100 \mathrm{~m}$ & 34.70 & 0.20 & 165.40 & 30.24 & - \\
\hline Dist_Natura_LP & Distance to the nearest landscape park & $100 \mathrm{~m}$ & 166.87 & 0.30 & 324.10 & 86.14 & - \\
\hline Dist_river & Distance to the nearest river & $100 \mathrm{~m}$ & 21.26 & 0.20 & 81.70 & 15.52 & $+/-$ \\
\hline Dist_stream & Distance to the nearest stream & $100 \mathrm{~m}$ & 6.55 & 0.10 & 32.40 & 4.96 & - \\
\hline Area_Forest $\mathrm{r} \leq 500$ & Forest area within the $500-\mathrm{m}$ radius & ha & 40.19 & 0.00 & 824.00 & 97.71 & + \\
\hline Area_Forest $\mathrm{r}=500-1500$ & Forest area within the $500-1500-\mathrm{m}$ radius & ha & 166.57 & 0.00 & 1692.00 & 213.89 & + \\
\hline Area_Forest $\mathrm{r}=1500-3000$ & Forest area above the $1500-\mathrm{m}$ radius & ha & 410.04 & 13.00 & 2238.00 & 388.15 & + \\
\hline Trees $r \leq 500$ & $\begin{array}{l}\text { Number of solitary trees within the } \\
500-\mathrm{m} \text { radius }\end{array}$ & No & 11.63 & 0 & 71 & 11.16 & + \\
\hline Trees $r=500-1500$ & $\begin{array}{l}\text { Number of solitary trees within the } \\
500-1500-\mathrm{m} \text { radius }\end{array}$ & No & 107.58 & 4 & 391 & 55.81 & + \\
\hline Trees $r \geq 1500$ & $\begin{array}{l}\text { Number of solitary trees above the } \\
1500-\mathrm{m} \text { radius }\end{array}$ & No & 372.22 & 33 & 803 & 142.11 & + \\
\hline Patch_Richness & $\begin{array}{l}\text { Number of patch types present within the } \\
500-\mathrm{m} \text { radius }\end{array}$ & No & 9.89 & 1 & 17 & 2.63 & + \\
\hline Shannon_diversity & $\begin{array}{l}\text { Shannon index of diversity of land-use patches } \\
\text { within the 500-m radius }\end{array}$ & Value & 1.28 & 0 & 2.18 & 0.31 & + \\
\hline Forest_Edge_Density & $\begin{array}{l}\text { The sum of the lengths }(\mathrm{m}) \text { of all the edge } \\
\text { segments in the landscape, divided by the total } \\
\text { landscape area }\left(\mathrm{m}^{2}\right) \text { within the } 500 \text {-m radius }\end{array}$ & Value & 0.11 & 0 & 2.52 & 0.15 & + \\
\hline
\end{tabular}

The neighborhood characteristics are expressed by the Euclidean distance to the nearest facility of a certain type, i.e., roads, schools, city center, and industrial areas. We logarithmically transform all of our distance variables, which enables us to show the relative change in the variable and not the absolute one. The potential to supply selected environmental services in the peri-urban areas of Wroclaw is high by various types of ecosystems $[36,37]$. We do not include any variables describing the condition of the ecosystems, although some authors recommend doing so in further research $[38,39]$. Others, though, conclude that the biocultural value does not significantly influence the property price $[40,41]$. 


\subsection{Methods}

Hedonic pricing is a revealed preference valuation method that is based on the assumption that individuals perceive a certain product or good as a bundle of its characteristics [42], and that various combination of the attributes can bring them different levels of utility [43]. The standard hedonic pricing equation is a regression function explaining the market price of a property:

$$
P=f(S, L, E)
$$

where $\mathrm{P}$ is the vector of the property price, $\mathrm{S}$ is the vector of the structural characteristics, $\mathrm{L}$ is the vector of the locational and neighborhood characteristics, and $\mathrm{E}$ is the vector of the environmental characteristics. The function can take linear, logistic, or other forms. The problem with the linear regression form is that it assumes the homoscedasticity of the variance of the error term. However, in practice, many spatial data are spatially heterogeneous, which applies to real estate prices at urban, suburban, and regional scales $[15,24]$. In our case, the problem with heteroscedasticity is also present, proved by Breusch-Pagan and White's tests [44]. The square meter prices of the vacant lots in our case study are also clustered and spatially autocorrelated. The Lagrange test indicated that there is autocorrelation of the lag and error term. It means that the price of a given plot is very much determined by the price of other neighboring plots. Very often, the prices are spatially clustered, meaning that similar values occur close to others. Many authors use semi-logarithmic or log-log specifications to address non-linearity in the house price function [23]. In order to deal with the spatial autocorrelation and autocorrelation of the lag and error term, we use the generalized spatial two-stage least squares (GSTSLS) procedure for estimating a spatial autoregressive model with autoregressive disturbances [45]. The generalized spatial two-stage least squares model has also been used in the studies of Seo, Golub, and Kuby [41], Fingleton and Fischer [46], and Ward and Pede [47]. We ran the model in the $\mathrm{R}$ environment and also in the GeoDaSpace software. It is based on the generalized method of moments (GMM) estimator [48] for estimating a spatial autoregressive model with autoregressive disturbances of order (SARAR). Kelejian and Prucha [48] provided the general equation for this model:

$$
\begin{gathered}
y_{n}=X_{n} \beta+\lambda W_{n} y_{n}+u_{n} \\
u_{n}=\rho M_{n} u_{n}+\varepsilon_{n}
\end{gathered}
$$

where $y_{n}$ is the vector of observation of the dependent variable, $X_{n}$ is the matrix of observations of $n$ exogenous variables, $W_{n}$ and $M_{n}$ are spatial weighting matrices, $\beta$ is the vector of regression parameters, $\lambda$ and $\rho$ are autoregressive parameters, $u_{n}$ is the vector of regression disturbances, and $\varepsilon_{n}$ is the vector of error term [48]. After trials of the number of nearest neighbors (from 10 to one), our spatial weighting matrices were built on a conceptualization of the spatial relationship of the five nearest neighbors. We have used GeoDa software to generate a spatial weights matrix.

The GWR model enabled us to calculate the coefficients for each location [49] rather than using a single coefficient in the global model [50]. We ran the analysis using the GWR 4.0.90 software provided by the development team of Tomoki Nakaya. The GWR key decisions boil down to the weighting function of the kernel and the selection of spatial bandwidth. The kernel can be either fixed or adaptive. We chose the adaptive one because it is more appropriate for observations that are clustered. The bandwidth method is the corrected Akaike information criterion (AICc). The general equation of the GWR model is:

$$
\begin{gathered}
y_{i}=\beta_{i 0}+\sum_{k=1}^{p} \beta_{i k} x_{i k}+\varepsilon_{i} \\
i=1,2,3, \ldots, n
\end{gathered}
$$

where $y_{\mathrm{i}}$ is the dependent variable at location $i$, which in our case is the price for the square meter of the parcel, $x_{i k}$ is the value of the kth explanatory variable at location $i, \beta_{\mathrm{ik}}$ is the local regression 
coefficient for the kth explanatory variable at location $i, \beta_{i 0}$ is the intercept parameter at location $i$, and $\varepsilon i$ is the random location specific error term. The GWR results are presented against the basic linear model estimated with the use of the ordinary least squares (OLS).

\section{Results}

The adjusted $\mathrm{R}^{2}$ for the local model $(0.63)$ is significantly higher than for the global models (0.46-0.45), and the corrected Akaike information criterion (AICc) is smaller for the local level than for the global, which mean that the local model explains more of the variability among the land parcel prices than the global ones (see Table 2). As expected, we observed the distance decay pattern of decreasing the value of the real estate along with the distance from the city center. The influence of this variable is strong in all of the models. In the lower quartile of the GWR results, most of the estimates indicate the negative relationship with the variables. For instance, the price of a parcel is expected to decrease for every 100 meters that it is further away from a bus stop, Natura 2000 site, or river. In the median of the GWR results, the positive impact of the accessibility of the roads and the railway is emerging. Interestingly, in the median results, the price of the parcels goes up along with the built-up industrial area and storage sites in the radiuses above $500 \mathrm{~m}$. The same is identified for the forest areas in radius $1500-3000 \mathrm{~m}$, although with almost insignificant magnitude.

The two global models seem to display a similar pattern of results; however, we have used different methods. The GSTSLS is based on the generalized method of moments (GMM), and it includes spatial lag and error [51], whereas the ordinary least square (OLS) is a basic linear regression. We cannot analyze the goodness of fit of these two methods by comparing R-square with the pseudo-R-square results. However, in the GSTSLS approach, the Rho $(\rho)$ and Lambda $(\lambda)$ are positive, and their p-values are zero. The most significant variables are the distance to the city center, primary school, and the distance to the landscape park. It is an anticipated result taking into consideration the demographics of the suburban population. In a sociological study, Kajdanek [52] described the typical inhabitants of this exact area as middle-class young couples with relatively small children who want to improve their quality of housing by moving to single-family estates at more natural areas in the suburbs. Less significant, although still important, are the distances to high schools and highways, and the diversity of the landscape in the neighborhood. Out of all the environmental amenities, the variables of the distances to the river and streams as well as landscape metrics of forest edge density, patch richness, and the number of trees in the radius above $1500 \mathrm{~m}$ were not statistically significant.

Proximity to the landscape park and diversity of land-use patches within the 500-m radius sites exerted the biggest influence on the price of the plots out of all of the environmental amenities included in this study in all three models. The marginal effects for those two variables are statistically significant, and their coefficients are about 0.2 . The premium price or implicit price of these attributes is calculated using the partial derivative of the variables' coefficients, the mean price of the square meter of the plot, and the mean value of the appropriate variable from Table 1. Estimate results for the landscape park based on the GSTSLS model coefficient imply that every $100 \mathrm{~m}$ closer to this environmental amenity increases the average price of the parcel by 0.15 PLN ( 0.04 USD). The median results of the GWR model show that the landscape park proximity gives a price premium of about $3 \%$. The medium coefficient of the GWR is the highest for the diversity of land-use patches within the 500-m radius of the parcel. It has a positive sign implying that by increasing the diversity by $1 \%$, one could increase the local premium by 25 PLN ( 6.9 USD). The median results of the GWR for the Natura 2000 delineated under the Birds Directive show that for every 100 meters further away from it, the price of the square meter of a vacant plot falls by 0.25 PLN ( 0.07USD). Interestingly, the Natura 2000 sites delineated by the Habitats Directive exert a positive impact on the price, meaning that along with the distance from these sites, the price of the parcel is supposed to increase. The directions of impacts of coefficients for the structural variable in OLS and GSTSLS are the same, and they mostly fulfill the expectations stated in Table 2. The only exception is the Natura 2000 sites, for which the price increases with every 100-m distance from the habitat areas. 
The price of the property is expected to rise along with the increasing surface of the forest nearby; however, the influence on the price is marginal. Out of the three forest area zones, only the forest hectares in the nearest proximity matter for the price of the parcel. The OLS results show that the forest area above the radius of $1500 \mathrm{~m}$ is also not significant, and in the GSTSLS model, it is significant at the $10 \%$ level. However, the influence of the forest area zone is very small anyway. The biggest influence that the forest exerts is in the southern part of the case study area, where the forest is scarce in comparison to the northern part (Figure 3). The number of trees displays the same pattern in terms of statistical significance; however, trees in the closest proximity exert a negative effect.

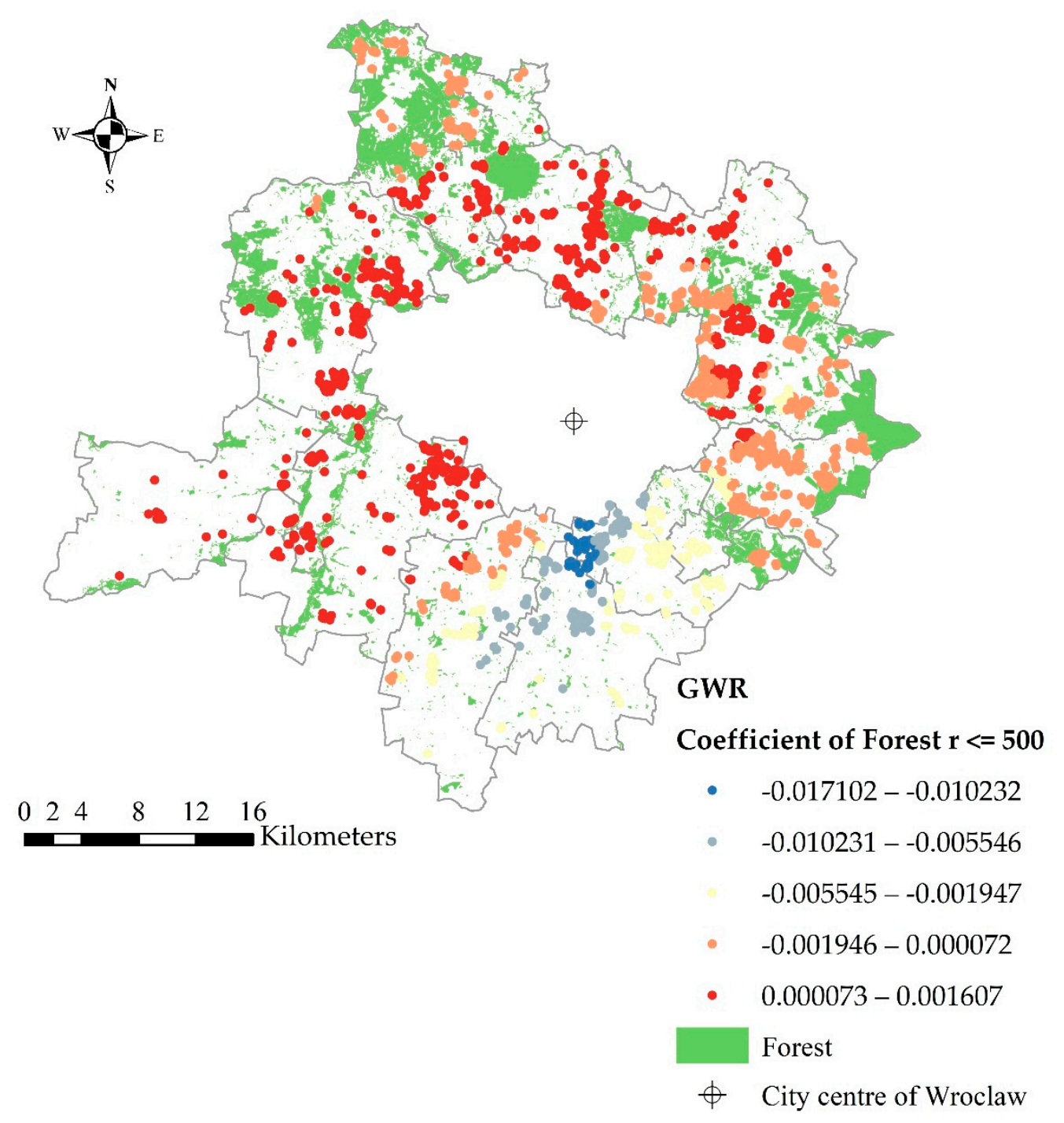

Figure 3. The coefficients of the geographically weighted regression (GWR) model of the forest in the radius within $500 \mathrm{~m}$. 
Table 2. Estimates from GWR, ordinary least square regression (OLS), and generalized spatial two-stage least squares (GSTSLS) models. AICc: corrected Akaike information criterion. " *", “**”, and “***” denote significance levels at $10 \%, 5 \%$ and $1 \%$ respectively. BIC: Bayesian Information Criterion.

\begin{tabular}{|c|c|c|c|c|c|c|c|c|c|}
\hline \multirow[b]{2}{*}{ Variable } & \multicolumn{3}{|c|}{ GWR } & \multicolumn{3}{|c|}{ OLS } & \multicolumn{3}{|c|}{ GSTSLS } \\
\hline & $\begin{array}{c}\text { Lower } \\
\text { Quartile }\end{array}$ & Median & $\begin{array}{c}\text { Upper } \\
\text { Quartile }\end{array}$ & Estimate & $\begin{array}{l}\text { Std. } \\
\text { Error }\end{array}$ & $p$-value & Estimate & $\begin{array}{l}\text { Std. } \\
\text { Error }\end{array}$ & $p$-value \\
\hline Intercept & -14.5592 & 8.0152 & 26.4625 & 10.0088 & 0.230 & $* * *$ & 9.8452 & 2.5232 & $* * *$ \\
\hline \multicolumn{10}{|c|}{ Locational and neighborhood variables } \\
\hline Ln_Dist_center & -2.5967 & 0.3971 & 8.0645 & -0.9437 & 0.0482 & $* * *$ & -0.9646 & 0.04691 & $* * *$ \\
\hline Ln_Dist_provincial road & -0.2650 & 0.0058 & 0.4460 & 0.0868 & 0.0181 & $* * *$ & 0.0800 & 0.0179 & $* * *$ \\
\hline Ln_Dist_highway & -5.7483 & -0.0104 & 1.6271 & -0.1276 & 0.0377 & $* * *$ & -0.1199 & 0.0369 & $* *$ \\
\hline Ln_Dist_railway & -0.0455 & 0.0467 & 0.1660 & -0.0392 & 0.0097 & $* * *$ & -0.0368 & 0.0093 & $* * *$ \\
\hline Ln_Dist_stop & -0.0860 & -0.0206 & 0.0819 & 0.0005 & 0.0148 & & 0.0034 & 0.0155 & \\
\hline Ln_Dist_primaryschool & -0.5443 & -0.3264 & -0.1117 & -0.2935 & 0.0266 & $* * *$ & -0.3006 & 0.0247 & $* * *$ \\
\hline Ln_Dist_highschool & -0.9875 & -0.2483 & 0.9544 & -0.2168 & 0.0428 & $* * *$ & -0.2014 & 0.0409 & $* * *$ \\
\hline Area_Ind $r=500$ & -0.0490 & -0.0149 & 0.0124 & -0.0028 & 0.0044 & & -0.0031 & 0.0040 & \\
\hline Area_ind $r=500-1500$ & -0.0012 & 0.0102 & 0.0257 & 0.0116 & 0.0013 & $* * *$ & 0.0116 & 0.0014 & $* * *$ \\
\hline Area_Ind $r=1500-3000$ & -0.0028 & 0.0025 & 0.0072 & 0.0022 & 0.0005 & $* * *$ & 0.0021 & 0.0005 & $* * *$ \\
\hline \multicolumn{10}{|c|}{ Environmental variables } \\
\hline Ln_Dist_Natura_bird & -3.2700 & -0.2127 & 0.9434 & -0.0628 & 0.0310 & $*$ & -0.0362 & 0.0321 & \\
\hline Ln_Dist_Natura_hab & -0.0489 & 0.0753 & 0.2381 & 0.0582 & 0.0104 & $* * *$ & 0.0575 & 0.1042 & $* * *$ \\
\hline Ln_Dist_Natura_LP & -8.3937 & -0.0526 & 5.2047 & -0.2531 & 0.0256 & $* * *$ & -0.2358 & 0.0262 & $* * *$ \\
\hline Ln_Dist_river & -0.0534 & 0.0872 & 0.1955 & 0.0183 & 0.0120 & & 0.0174 & 0.0128 & \\
\hline Ln_Dist_stream & 0.0018 & 0.0490 & 0.0782 & 0.0083 & 0.0095 & & 0.0084 & 0.0089 & \\
\hline Area_Forest $\mathbf{r}=500$ & -0.0077 & -0.0004 & 0.0008 & 0.0005 & 0.0001 & $* * *$ & 0.0005 & 0.0001 & $* * *$ \\
\hline Area_Forest $r=500-1500$ & -0.0006 & -0.0000 & 0.0006 & 0.0001 & 0.0001 & * & 0.0001 & 0.0000 & $* * *$ \\
\hline Area_Forest $r=1500-3000$ & -0.0004 & 0.0001 & 0.0006 & 0.0001 & 0.0000 & & 0.0000 & 0.0000 & * \\
\hline Trees $\mathrm{r}<=500$ & -0.0070 & -0.0029 & 0.0022 & -0.0032 & 0.0008 & $* * *$ & -0.0032 & 0.0008 & $* * *$ \\
\hline Trees $r=500-1500$ & -0.0010 & 0.0008 & 0.0023 & 0.0006 & 0.0002 & $*$ & 0.0005 & 0.0002 & $* *$ \\
\hline Trees $r=1500-3000$ & -0.0015 & -0.0001 & 0.0010 & 0.0000 & 0.0001 & & 0.0000 & 0.0000 & \\
\hline Patch_Richness & -0.0391 & -0.0116 & 0.0150 & 0.0033 & 0.0047 & & 0.0043 & 0.0048 & \\
\hline Shannon_diversity & 0.1014 & 0.2983 & 0.6067 & 0.2026 & 0.0398 & $* * *$ & 0.1965 & 0.0417 & $* * *$ \\
\hline Forest_Edge_Density & -0.2284 & -0.0382 & 0.1599 & -0.0731 & 0.0553 & & -0.0652 & 0.0835 & \\
\hline AICc: & 2290.7219 & & & 2866.8031 & & & & & \\
\hline BIC/MDL & 4700.5571 & & & & & & & & \\
\hline R-square & 0.7060 & & & 0.4659 & & & & & \\
\hline Adjusted R-square: vmroeng & 0.6345 & & & 0.4608 & & & & & \\
\hline Pseudo R-square: & & & & & & & 0.5096 & & \\
\hline Spatial Pseudo R-square: & & & & & & & 0.4489 & & \\
\hline
\end{tabular}

\section{Discussion}

Peri-urban areas stay under the influence of a city while struggling to preserve their rural character. The ongoing land-use changes in peri-urban areas are significant and have major environmental impacts. In the case of Poland, new single-family housing and industrial developments are major drivers of change supported by the funding from the core cities. Therefore, the sustainable management of the urban-rural fringe, including socioeconomic and environmental aspects, should be supported by non-monetary [53] and monetary analysis. In this study, we sought to uncover the value of environmental amenities in peri-urban areas using the hedonic pricing approach, and reveal the environmental amenity preferences of the peri-urban new inhabitants embedded in the real estate market in Poland.

Our results show that the major factor influencing the price of vacant lots for housing in the peri-urban areas is their location in terms of the distance to the core city center. The other locational characteristics of plots, such as the distance to schools, roads, and railways, are also significant and play an important role for households. These results are supported by the results of all three models, and they follow patterns that have been identified in other studies [19,54]. The impact of environmental amenities on vacant plot prices in peri-urban areas (contributing to about $3 \%$ of the real estate price) is comparable in magnitude to the results of other hedonic pricing studies [55]. However, blue infrastructure, as in the case of the river and streams, did not prove to be statistically significant relative to the above-mentioned factors.

Out of all the environmental amenities included in our study, the proximity to protected areas, such as Natura 2000 sites and landscape parks, and diversity of land-use patches within the 500-m 
radius around the sites, exert the strongest influence on the plot's price in all of the models. The protection regime of Natura 2000 sites is relatively strong compared to the landscape park area. In the landscape park area, a variety of economic activities are possible, such as agricultural or industrial production. Investments within and close to Natura 2000 sites are limited, and require environmental impact assessments and special permissions. The price of the property is expected to rise along with the increasing surface of the forest close by; however, the influence on the price is marginal. The number of trees does not increase the value of the parcels. Solitaire trees are evenly distributed in the case study area, and only about $7 \%$ of them are standing along provincial roads. This $7 \%$ may be contributing to the negative sign of the estimates for the number of trees within the 500-m radius.

The results provide information on the preferences of people buying vacant lots for single-family housing at the urban-rural fringe concerning environmental amenities. The environmental amenities are not at the top of the preference hierarchy of new dwellers of peri-urban areas when choosing the location of living. Although the ecological awareness of Poles has been increasing over the last few years, it does not influence the choice of place to settle down more than practical implications such as traveling time and distance to the core city, where most of the people work or study, shop, and entertain. However, there is a certain preference for the environmental amenities of peri-urban areas that can be estimated in monetary terms by using the hedonic pricing method. The monetary values are derived from the real estate market by showing the price premium for the plot devoted to single-family housing. This study provides evidence of a monetized dimension of preference toward environmental amenities that could be considered in the land use trade-off assessments in the peri-urban planning process. Finally, it seems that the diversity of land uses close to the sites and some protected areas nearby are the most preferable environmental amenities. The first one confirms the assumption of landscape and ecosystem service assessments [56] concerning landscape diversity preference. The second finding indicates a clear preference for a protection regime in comparison to green areas, which are not legally protected. Protected areas represent high nature conservation value areas, and guarantee ecological quality. The preferences that have been identified in this study concern the current spatial distribution, size, and relative abundance of the selected protected areas (Natura 2000 sites and landscape parks, as shown in Figure 1). Our findings provide information for policy makers about the new peri-urban inhabitants' preferences related to the current land-use management, with a special focus on green open areas. We contribute to the existing body of research with the peri-urban case study that provides the magnitude of impacts of the selected environmental amenities on the vacant lots that do not possess any structural characteristics. Our study represents one of the few environmental valuation examples from Central Europe, especially from Poland. To the best of our knowledge, it is the only attempt for estimating the value and uncovering the preferences for peri-urban environmental amenities using a wide range of variables describing typical environmental amenities at the urban-rural fringe in Poland using the hedonic pricing method.

Our results correspond with the messages from hedonic urban [57-59] and peri-urban environmental amenities studies. Our findings are in line with the results of Nilsson [24], which stated that the economic effects of the environmental amenities outside the cities are rather low. The forest variables' results do not support the findings by Cho et al. [60] on the non-urbanites' preferences for fragmented forest patches rather than larger forest blocks, nor those of Poudyal et al. [61], which showed that house prices significantly increase in urban neighborhoods with larger but fewer open spaces. Other literature findings reveal that tree cover contributes to the residential estate value in the suburban and peri-urban areas [62,63], but mainly within a small buffer of $250 \mathrm{~m}$ of a house [54]. Green open spaces, in particular forests [64] and lakes [17], also add value to parcels. Water bodies are more valuable in locations with protected natural areas [65]. The landscape metrics of the peri-urban landscape have been investigated in terms of their diversity and fragmentation $[9,66]$. Geoghegan, Wainger, and Bockstael [67] found that these features are desirable in the suburban areas that are closest to city borders, which is possibly due to accessibility to different services. The literature suggests that the price premium of the forest in the peri-urban areas is significantly lower than that in urban 
settings [66]. Also, the different direction of impact is identified for trees, which is positive in the urban environment and negative in the suburban environment [38]. The message from many urban studies [67] is that the environmental amenities increased the house sale price only in its closest proximity, within the buffer ranging from $100 \mathrm{~m}[68,69]$ to $250 \mathrm{~m}$ [54], $500 \mathrm{~m}$ [55], and up to $2000 \mathrm{~m}$ [18]. The $1 \%$ increase of green areas, in general, may lead to an approximate increase of 0.0023 [18] or $0.07 \%[70]$ in the expected sales price of the house. The view on the green space from the residential amenity matters a lot, i.e., it gives a price premium of almost $6 \%$ [71], and of $5 \%$ for both forest [66] and water views [72].

The hedonic pricing method has been improved not only in terms of different spatial applicability, but also econometric methods supporting regression analyses. The linear ordinary least square (OLS) regression is a basic type of regression that is often used to confront the results of other methods. The OLS model assumes homoscedasticity, meaning the homogeneity of variance, which is very often not the case for spatial phenomena. Several different spatial models have been developed to better address the lag and error spatial dependences. The use of spatial lag (SAR), spatial error (SEM), or spatial durbin (SDM) models is quite common in hedonic case studies. We have used a spatial autoregressive model with autoregressive disturbances of order (SARAR) model because it worked the best for us in addressing the spatial autocorrelation and autocorrelation of the lag and error term. Some other procedures are also possible, such as using a fixed effects estimator or general additive (GAM) model.

A limitation of this case study is the lack of detailed information about the parcel's transaction purpose, which would guarantee that the land is devoted to single-family housing. We tried to overcome this limitation by taking the assumptions concerning the size of the plots, the price per square meter, and planning documents to extract appropriate parcels out of all the land transactions registered in this area. We tested the assumptions with several statistical tests of regression models. The next limitation concerns the omitted variables, which we tried to control for in the models. However, if we were able to obtain some socioeconomic data that would feed into crime and social cohesion explanatory variables, the analysis would significantly benefit from that.

\section{Conclusions}

This study assessed the influence of the selected environmental amenities on the price of land parcels for single-family housing lots in the peri-urban municipalities of Wroclaw. The results of the analysis provide useful insights for policy makers as well as planners and the administration of so-called "green departments" on the value of trees, forests, protected areas, and landscape diversity in peri-urban settings. We applied the hedonic pricing method to the Central European case study of the peri-urban areas of the city of Wroclaw, Poland, using a local model (a geographically weighted regression) and two global models (generalized spatial two-stage least squares and ordinary least square). The use of undeveloped land parcels enabled us to exclude the influence of the building's state and elaborate only on the locational and neighborhood characteristics.

The major findings of this study provide insights into the magnitude of the impact of peri-urban environmental amenities, such as landscape diversity in the radius of $500 \mathrm{~m}$ from the center of a parcel, protected areas (Natura 2000 sites and landscape park), forest, individual trees, rivers, and streams on plot prices. Undoubtedly, the distance to the city center is a major determinant of the price of the plot for housing. Then, education and transportation aspects are the second most important. Later, the existence of protected areas and landscape diversity in close proximity might increase the price of the lot for single-family housing. Therefore, investing in improving the provision of environmental amenities in peri-urban area enhances the possibility of lower-income families enjoying the positive effects of greenery, even at the relatively small price premium in the housing market.

Finally, with the use of the hedonic pricing revealed preference method, researchers can assist decision makers with monetary estimations of environmental amenities based on real estate market prices. Nevertheless, this method enables assigning the value of green elements that was captured by the market and which constitutes only a part of the total value of environmental goods and services. 
Author Contributions: Conceptualization, M.S. and T.L.; methodology, M.S.; investigation, M.S.; data curation, M.S. and T.L.; writing—original draft preparation, M.S.; writing—review and editing, M.S.; visualization, M.S.; supervision, S.S.

Funding: Part of this research was supported by the Polish National Science Centre, grant number 2016/23/N/HS4/03416.

Acknowledgments: The authors would like to thank Irene Ring for constructive discussions and very helpful comments on an earlier version of this manuscript. We would also like to thank three anonymous reviewers for providing very useful comments and suggestions. Finally, we acknowledge the financial support from Wroclaw University of Environmental and Life Sciences.

Conflicts of Interest: The authors declare no conflict of interest.

\section{References}

1. Camps-Calvet, M.; Langemeyer, J.; Calvet-mir, L.; Gómez-Baggethun, E. Ecosystem services provided by urban gardens in Barcelona, Spain: Insights for policy and planning. Environ. Sci. Policy 2016, 62, 14-23. [CrossRef]

2. McPhearson, T.; Andersson, E.; Elmqvist, T.; Frantzeskaki, N. Resilience of and through urban ecosystem services. Ecosyst. Serv. 2014, 12, 152-156. [CrossRef]

3. Andersson, E.; Barthel, S.; Borgstro, S.; Colding, J.; Elmqvist, T.; Folke, C.; Gren, A. Reconnecting Cities to the Biosphere: Stewardship of Green Infrastructure and Urban Ecosystem Services. Ambio 2014, 43, 445-453. [CrossRef]

4. Haines-Young, R.; Potschin, M. The links between biodiversity, ecosystem services human well-being. In Ecosystem Ecology: A New Synthesis; Raffaelli, D.G., Frid, C.L.J., Eds.; Cambridge University Press: Cambridge, UK, 2010; pp. 110-139.

5. Hennig, E.I.; Schwick, C.; Orlitová, E.; Kienast, F.; Jaeger, J.A.G. Multi-scale analysis of urban sprawl in Europe: Towards a European de-sprawling strategy. Land Use Policy 2015, 49, 483-498. [CrossRef]

6. Long, H.; Liu, Y.; Hou, X.; Li, T.; Li, Y. Effects of land use transitions due to rapid urbanization on ecosystem services: Implications for urban planning in the new developing area of China. Habitat Int. 2014, 44, 536-544. [CrossRef]

7. Walz, U.; Łowicki, D. Gradient of Land Cover and Ecosystem Service Supply Capacities-A Comparison of Suburban and Rural Fringes of Towns Dresden (Germany) and Poznan (Poland). Procedia Earth Planet. Sci. 2015, 15, 495-501. [CrossRef]

8. The Economics of Ecosystems and Biodiversity (TEEB) Ecological and Economic Foundations; Pushpam Kumar (Ed.) Earthscan: London, UK; Washington, DC, USA, 2010.

9. Cho, S.; Poudyal, N.C.; Roberts, R.K. Spatial analysis of the amenity value of green open space. Ecol. Econ. 2008, 66, 403-416. [CrossRef]

10. Anderson, S.T.; West, S.E. Open space, residential property values, and spatial context. Reg. Sci. Urban Econ. 2006, 36, 773-789. [CrossRef]

11. Morancho, A.B. A hedonic valuation of urban green areas. Landsc. Urban Plan. 2003, 66, 35-41. [CrossRef]

12. Waltert, F.; Schläpfer, F. Landscape amenities and local development: A review of migration, regional economic and hedonic pricing studies. Ecol. Econ. 2010, 70, 141-152. [CrossRef]

13. Tyrvainen, L. The amenity value of the urban forest: An application of the hedonic pricing method. Landsc. Urban Plan. 1997, 37, 211-222. [CrossRef]

14. Fotheringham, A.S.; Crespo, R. Exploring, modelling and predicting spatiotemporal variations in house prices. Ann. Reg. Sci. 2015, 417-436. [CrossRef]

15. Schläpfer, F.; Waltert, F.; Segura, L.; Kienast, F. Valuation of landscape amenities: A hedonic pricing analysis of housing rents in urban, suburban and periurban Switzerland. Landsc. Urban Plan. 2015, 141, $24-40$. [CrossRef]

16. Łowicki, D.; Piotrowska, S. Monetary valuation of road noise. Residential property prices as an indicator of the acoustic climate quality. Ecol. Indic. 2015, 52, 472-479. [CrossRef]

17. Sander, H.A.; Polasky, S. The value of views and open space: Estimates from a hedonic pricing model for Ramsey County, Minnesota, USA. Land Use Policy 2009, 26, 837-845. [CrossRef]

18. Melichar, J.; Kaprová, K. Revealing preferences of Prague' s homebuyers toward greenery amenities: The empirical evidence of distance-Size effect. Landsc. Urban Plan. 2013, 109, 56-66. [CrossRef] 
19. Liebelt, V.; Bartke, S.; Schwarz, N. Revealing Preferences for Urban Green Spaces: A Scale-sensitive Hedonic Pricing Analysis for the City of Leipzig. Ecol. Econ. 2018, 146, 536-548. [CrossRef]

20. Waltert, F.; Schulz, T.; Schläpfer, F. The role of landscape amenities in regional development: Evidence from Swiss municipality data. Land Use Policy 2011, 28, 748-761. [CrossRef]

21. Gibbons, S.; Mourato, S.; Resende, G.M. The Amenity Value of English Nature: A Hedonic Price Approach. Environ. Resour. Econ. 2014, 57, 175-196. [CrossRef]

22. Bulteau, J.; Feuillet, T.; Le Boennec, R. Spatial Heterogeneity of Sustainable Transportation Offer Values: A Comparative Analysis of Nantes Urban and Periurban/Rural Areas (France). Urban Sci. 2018, 2, 14. [CrossRef]

23. Helbich, M. Do suburban areas impact house prices? Environ. Plan. B Plan. Des. 2015, 42, 431-449. [CrossRef]

24. Nilsson, P. Natural amenities in urban space-A geographically weighted regression approach. Landsc. Urban Plan. 2014, 121, 45-54. [CrossRef]

25. Zhang, X.; He, J.; Deng, Z.; Ma, J.; Chen, G.; Zhang, M.; Li, D. Comparative changes of influence factors of rural residential area based on spatial econometric regression model: A case study of Lishan Township, Hubei Province, China. Sustainability 2018, 10, 3403. [CrossRef]

26. Ravetz, J.; Fertner, C.; Nielsen, T.S. The Dynamics of Peri-Urbanization. In Peri-Urban Futures: Scenarios and Models for Land use Change in Europe; Springer: Berlin/Heidelberg, Germany, 2013; pp. 1-453. ISBN 9783642305290.

27. Lin, Y.; Ma, Z.; Zhao, K.; Hu, W.; Wei, J. The impact of population migration on urban housing prices: Evidence from China's major cities. Sustainability 2018, 10, 3169. [CrossRef]

28. Tokarczyk-Dorociak, K.; Kazak, J.; Szewrański, S. The Impact of a Large City on Land Use in Suburban Area - The Case of Wrocław (Poland). J. Ecol. Eng. 2018, 19, 89-98. [CrossRef]

29. Szewrański, S.; Kazak, J.; Żmuda, R.; Wawer, R. Indicator-based assessment for soil resource management in the Wrocław Larger Urban Zone of Poland. Polish J. Environ. Stud. 2017, 26, 2239-2248. [CrossRef]

30. Przybyła, K.; Kulczyk-Dynowska, A.; Kachniarz, M. Quality of Life in the Regional Capitals of Poland. J. Econ. Issues 2014, 48, 181-195. [CrossRef]

31. Świąder, M.; Szewrański, S.; Kazak, J. Foodshed as an Example of Preliminary Research for Conducting Environmental Carrying Capacity Analysis. Sustainability 2018, 10, 882. [CrossRef]

32. Solecka, I.; Sylla, M.; Świąder, M. Urban Sprawl Impact on Farmland Conversion in Suburban Area of Wroclaw, Poland. In IOP Conf. Series: Materials Science and Engineering; IOP Publishing: Bristol, UK, 2017; Volume 245, p. 072002.

33. Hełdak, M.; Płuciennik, M. Costs of Urbanisation in Poland, Based on the Example of Wrocław. In IOP Conf. Series: Materials Science and Engineering; IOP Publishing: Bristol, UK, 2017; Volume 245, p. 072003.

34. Krajewski, P.; Solecka, I.; Mrozik, K. Forest Landscape Change and Preliminary Study on Its Driving Forces in Ślęża Landscape Park (Southwestern Poland) in 1883-2013. Sustainability 2018, 10, 4526. [CrossRef]

35. Suchecki, B. Spatial Econometrics. Methods and Models of Spatial Data Analysis; C.H. Beck: Warsaw, Poland, 2010; ISBN 978-83-255-1122-7.

36. Sylla, M. Mapping and assessment of the potential to supply selected ecosystem services at sub-regional scale. The example of Wroclaw and its surrounding municipalities. Econ. Environ. 2016, 4, 87-98.

37. Raszka, B.; Hełdak, M. Ecosystem Service Provision in the Spatial Policy of the Wroclaw County; Wydawnictwo Uniwersytetu Przyrodniczego we Wrocławiu: Wrocław, Poland, 2013; ISSN 2083-5531.

38. Saphores, J.; Li, W. Estimating the value of urban green areas: A hedonic pricing analysis of the single family housing market in Los Angeles, CA. Landsc. Urban Plan. 2012, 104, 373-387. [CrossRef]

39. Escobedo, F.J.; Adams, D.C.; Timilsina, N. Urban forest structure effects on property value. Ecosyst. Serv. 2015, 12, 209-217. [CrossRef]

40. Czembrowski, P.; Łaszkiewicz, E.; Kronenberg, J. Urban Forestry \& Urban Greening Bioculturally valuable but not necessarily worth the price: Integrating different dimensions of value of urban green spaces. Urban For. Urban Green. 2016, 20, 89-96. [CrossRef]

41. Seo, K.; Golub, A.; Kuby, M. Combined impacts of highways and light rail transit on residential property values: A spatial hedonic price model for Phoenix, Arizona. J. Transp. Geogr. 2014, 41, 53-62. [CrossRef]

42. Lancaster, K. A new approach to consumer theory. J. Polit. Econ. 1966, 74, 132-157. [CrossRef]

43. Rosen, S. Hedonic prices and implicit markets: Product differentiation in pure competition. J. Polit. Econ. 1974, 82, 34-55. [CrossRef] 
44. White, H. A heteroskedasticity-consistent covariance matrix estimator and a direct test for heteroskedasticity. Econometrica 1980, 48, 817-838. [CrossRef]

45. Drukker, D.M.; Prucha, I.R. Maximum likelihood and generalized spatial two-stage least-squares estimators for a spatial-autoregressive model with spatial-autoregressive disturbances. Stata J. 2013, 13, 221-241. [CrossRef]

46. Fingleton, B.; Fischer, M.M. Neoclassical theory versus new economic geography: Competing explanations of cross-regional variation in economic development. Ann. Reg. Sci. 2010, 44, 467-491. [CrossRef]

47. Ward, P.S.; Pede, V.O. Capturing social network effects in technology adoption: The spatial diffusion of hybrid rice in Bangladesh. Aust. J. Agric. Resour. Econ. 2015, 59, 225-241. [CrossRef]

48. Kelejian, H.H.; Prucha, I.R. A Generalized Spatial Two-Stage Least Squares Procedure for Estimating a Spatial Autoregressive Model with Autoregressive Disturbances. J. Real Estate Financ. Econ. 1998, 17, 99-121. [CrossRef]

49. Ma, Y.; Gopal, S. Geographically weighted regression models in estimating median home prices in towns of Massachusetts based on an urban sustainability framework. Sustainability 2018, 10, 1026. [CrossRef]

50. Fotheringham, A.S.; Brunsdon, C.; Charlton, M. Geographically Weighted Regression: The Analysis of Spatially Varying Relationships; John Wiley and Sons: Chichester, UK, 2002; ISBN 978-0-471-49616-8.

51. Kelejian, H.H.; Prucha, I.R. Specification and estimation of spatial autoregressive models with autoregressive and heteroskedastic disturbances. J. Econom. 2010, 157, 53-67. [CrossRef] [PubMed]

52. Kajdanek, K. Between City and Village. Suburbanization Based on the Suburban Settlements of Wrocław; "NOMOS" Publishing House: Cracow, Poland, 2011; ISBN 978-83-7688-048-8.

53. Niedźwiecka-Filipiak, I.; Rubaszek, J.; Potyrała, J.; Filipiak, P. The Method of Planning Green Infrastructure System with the Use of Landscape-Functional Units (Method LaFU) and its Implementation in the Wrocław Functional Area (Poland). Sustainability 2019, 11, 394. [CrossRef]

54. Sander, H.; Polasky, S.; Haight, R.G. The value of urban tree cover: A hedonic property price model in Ramsey and Dakota Counties, Minnesota, USA. Ecol. Econ. 2010, 69, 1646-1656. [CrossRef]

55. Czembrowski, P.; Kronenberg, J. Hedonic pricing and different urban green space types and sizes: Insights into the discussion on valuing ecosystem services. Landsc. Urban Plan. 2016, 146, 11-19. [CrossRef]

56. Hermes, J.; Albert, C.; Haaren, C. Von Assessing the aesthetic quality of landscapes in Germany. Ecosyst. Serv. 2018, 31, 296-307. [CrossRef]

57. Deilami, K.; Kamruzzaman, M.; Hayes, J.F. Correlation or causality between land cover patterns and the urban heat island effect? Evidence from Brisbane, Australia. Remote Sens. 2016, 8, 716. [CrossRef]

58. Giannias, D.; Sfakianaki, E. Classifications of environmental quality effects: The case of Canadian cities. Econ. Manag. J. 2014, 17, 45-60. [CrossRef]

59. Giannias, D.A. A quality of life based ranking of Canadian cities. Urban Stud. 1998, 35, 2241-2251. [CrossRef]

60. Cho, S.; Jung, S.J.; Kim, S.G. Valuation of Spatial Configurations and Forest Types in the Southern Appalachian Highlands. Environ. Manag. 2009, 43, 628-644. [CrossRef] [PubMed]

61. Poudyal, N.C.; Hodges, D.G.; Tonn, B.; Cho, S.H. Valuing diversity and spatial pattern of open space plots in urban neighborhoods. For. Policy Econ. 2009, 11, 194-201. [CrossRef]

62. Morales, D.J. Contribution of trees to residential property value. J. Arboric. 1980, 6, 305-308.

63. Morales, D.J.; Micha, F.R.; Weber, R.L. Two methods of valuating trees on residential sites. J. Arboric. 1983, 9 , 21-24.

64. Mansfield, C.; Pattanayak, S.K.; McDow, W.; McDonald, R.; Halpin, P. Shades of Green: Measuring the value of urban forests in the housing market. J. For. Econ. 2005, 11, 177-199. [CrossRef]

65. Sander, H.A.; Zhao, C. Urban green and blue: Who values what and where? Land Use Policy 2015, 42, $194-209$. [CrossRef]

66. Tyrvainen, L.; Miettinen, A. Property Prices and Urban Forest Amenities. J. Environ. Econ. Manag. 2000, 39, 205-223. [CrossRef]

67. Geoghegan, J.; Wainger, L.A.; Bockstael, N.E. Spatial landscape indices in a hedonic framework: an ecological economics analysis using GIS. Ecol. Econ. 1997, 23, 251-264. [CrossRef]

68. Donovan, G.H.; Butry, D.T. Urban Forestry \& Urban Greening The effect of urban trees on the rental price of single-family homes in Portland, Oregon. Urban For. Urban Green. 2011, 10, 163-168. [CrossRef]

69. Hjerpe, E.; Kim, Y.S.; Dunn, L. Forest density preferences of homebuyers in the wildland-urban interface. For. Policy Econ. 2016, 70, 56-66. [CrossRef] 
70. Conway, D.; Li, C.Q.; Wolch, J.; Kahle, C.; Jerrett, M. A spatial autocorrelation approach for examining the effects of urban greenspace on residential property values. J. Real Estate Financ. Econ. 2010, 41, 150-169. [CrossRef]

71. Panduro, T.E.; Veie, K.L. Classification and valuation of urban green spaces-A hedonic house price valuation. Landsc. Urban Plan. 2013, 120, 119-128. [CrossRef]

72. Jim, C.Y.; Chen, W.Y. Impacts of urban environmental elements on residential housing prices in Guangzhou (China). Landsc. Urban Plan. 2006, 78, 422-434. [CrossRef] 